\title{
Cadê as crianças negras que estão aqui?: o racismo (não) comeu. ${ }^{1}$
}

Where are the black children who are here?: racism (don't) ate them

Míghian Danae Ferreira Nunes²

Resumo: O racismo está presente nas relações sociais e se manifesta de maneira complexa, alcançando as crianças em intrincadas conexões com outras categorias, a saber, sexo-gênero, origem e idade. Este artigo está dividido em três seções: na primeira delas, realizo uma breve apresentação de alguns estudos na área das ciências humanas sobre as crianças negras, produzidos a partir da década de cinquenta no Brasil até os dias atuais, buscando compreender qual a representação da criança negra brasileira foi por eles produzida. Na segunda seção, discuto as possibilidades de pensar estudos mais recentes sobre crianças negras que agreguem observações realizadas pelos estudos pioneiros, mas sem esquecer que as crianças negras estão presentes não apenas pelo que lhes faltam (ou dizem-lhes faltar) e sofrem, mas também por aquilo que são. Compreendo assim ser possível organizar outros modos de vista para estas crianças que não apenas aqueles ancorados na exclusão, para que não sejam engolidas pelo racismo instalado não apenas em nossa organização social, mas também em nosso modelo de fazer ciência. Em uma última seção, a partir da

\footnotetext{
${ }^{1}$ Inspirei-me em algo que ouvi da profa. Dra. Patrícia Prado numa aula em abril de 2014, quando disse ter escrito um texto quando ainda era estudante de doutorado com o título "Cadê a criança que estava aqui? Rousseau comeu", ou algo parecido. Achei que a paráfrase era um bom mote à reflexão sobre as crianças negras. ${ }^{2}$ Doutoranda em Educação na área da Sociologia da Educação na FEUSP. Faz parte do Grupo de Pesquisa Sociologia da Infância e Educação Infantil (GEPSI) da Faculdade de Educação da USP e do Grupo de Estudos e Pesquisas em Educação da Universidade Lueji A'Nkonde, de Angola (GEPEULAN) da Faculdade de Educação da USP. E-mail: mighiandanae@yahoo.com.br
}

Latitude, Vol. 10, nํㅡㄹ 2, pp. 383-423, 2016

DOI: https://doi.org/10.28998/2179-5428.20160209 
Cadê as crianças negras que estão aqui?': o racismo (não) comeu’

constituição de novos problemas, apresento aquilo que identifico como contribuição das crianças negra para os estudos sociais da infância. As crianças negras brasileiras estão vivas.

Palavras-chave: crianças negras; raça; racismo; estudos sociais da infância

\begin{abstract}
Racism is present within the social relationships and expresses itself in a complex way, reaching the children through their confused connections, i.e. sex/type, origin and age. This paper is shared into three sections: in the first one I briefly introduce any studies in the area of human sciences about black children, published from the fifties until now, devoted to the comprehension of which representation of the brazilian black child was built through them. In the second section I dicuss the possibility to envisage studies on black children that take into account the observations carried out from these pioneering studies, but without forgetting that the black children are present, with colour and body, not only for what is lacking for them or for their suffering, but also for what they have and are. Therefore, I understand that it is possible to elaborate another point of view about these children not only for those rooted in the exclusion and discrimination, in order to avoid them to be swallowed up by racism installed not only in our social organization, but also in our scientific process. In the last section I conclude by what appears to me as being contributions that the black children can bring to the social studies on infancy, starting from new questions and new problems. The brazilian black children are alive.
\end{abstract}

Keywords: black children; race; racism; social studies of childhood.

As crianças negras brasileiras estão vivas. Inicio este artigo com uma afirmação que, se parece óbvia, demonstra a escolha de analisar, nas páginas que seguem, como elas continuam a existir, a despeito do exíguo número de pesquisas acadêmicas ${ }^{3}$ que as encerram em estudos que, ao se

\footnotetext{
${ }^{3}$ Essa constatação é feita na revisão de literatura realizada por Alvim e Valladares
} (1988), em que concluem ser a questão racial um "tema a pertinente ao se pensar a 
ocuparem da denúncia do racismo presente em nossa sociedade brasileira, confere-lhes pouca visibilidade e participação social. A provocação que o título sugere nos convoca apensar como o racismo tem apagado a presença das crianças negras brasileiras mesmo nos espaços em que elas estão presentes, refletindo sobre de que forma é possível congregar a luta antirracista e estudos que demonstrem os modos como as crianças negras tem (re)existido cotidianamente.

O racismo é um elemento estrutural/estruturante das vidas em sociedade, presente nas relações sociais e que se manifesta de maneira complexa quando relacionado a aspectos intergeracionais e de gênero. $\mathrm{Na}$ primeira parte deste artigo, realizo uma breve apresentação de alguns estudos na área das ciências humanas sobre as crianças negras produzidos a partir da década de cinquenta no Brasil até os dias atuais, analisando de que modo elas aparecem nestes textos ${ }^{4}$.

Além de apresentar o racismo vivido no cotidiano das escolas a partir de injúrias e xingamentos aos quais as crianças negras estão sujeitas e como, a partir desta realidade, as crianças negras acabavam por não construir a autoestima necessária para reagir, estas pesquisas também se ocuparam de denunciar o racismo institucional ${ }^{5}$ presente em instituições escolares, mesmo não assim denominando a ação das instituições (BICUDO, 1955; GINSBERG, 1955; GONÇALVES, 1985; OLIVEIRA, 1994; GODOY, 1996; CAVALLEIRO, 1998; FAZZI, 2000; OLIVEIRA, 2004; TRINIDAD, 2011; GAUDIO, 2013).

Assim, busco nesta primeira seção compreender qual a representação da criança negra brasileira foi/tem sido construída nestes

infância pobre frente à sociedade nacional" (p. 22). Irene Rizzini (2008, p. 80) reforça a observação.

${ }^{4} \mathrm{~A}$ maior parte das pesquisas aqui apresentadas ocupou-se das crianças pequenas (03-07 anos), mas é possível encontrar alguns trabalhos que agregaram crianças com idades maiores (09-15 anos).

${ }^{5}$ “O racismo institucional é o fracasso das instituições e organizações em prover um serviço profissional e adequado às pessoas em virtude de sua cor, cultura, origem racial ou étnica. Ele se manifesta em normas, práticas e comportamentos discriminatórios adotados no cotidiano do trabalho [...] Em qualquer caso, o racismo institucional sempre coloca pessoas de grupos raciais ou étnicos discriminados em situação de desvantagem no acesso a benefícios gerados pelo Estado e por demais instituições e organizações"' (CRI, 2006, p. 22). 
estudos e se é possível organizar outros modos de vista para estas crianças que não apenas aqueles ancorados na exclusão e discriminação, para que assim não sejam engolidas pelo racismo que se espraia não apenas em nossa sociedade, mas também em nosso modelo de fazer ciência.

Na segunda parte do artigo, discuto as possibilidades de pensar os estudos sobre as crianças negras que agreguem as observações realizadas por estes estudos pioneiros, mas sem esquecer que as crianças negras estão presentes, em cor e corpo, não apenas pelo que lhes faltam ou por aquilo que sofrem. Com essa afirmação, considero que a trajetória dos estudos acadêmicos apresentados na primeira parte deste artigo oferece a fundamentação necessária para que possamos pensar em estudos que levem em conta a ação social das crianças negras e a incorporação de novas visões sobre o tema em questão, por exemplo, a visão que as próprias crianças negras tem de suas vidas e como atuam na sociedade da qual também fazem parte (DAMIÃO, 2007; SANTIAGO, 2014; PAULA, 2014; SOUZA, 2015).

Ao defender que as crianças negras sejam vistas também pelo que são, estes estudos coadunam-se com a visão proposta pelos cientistas sociais que, apesar de não esconderem o horror que foi a escravização, ocuparam-se também dos registros das muitas e significativas histórias vividas pelas pessoas escravizadas (CHALHOUB, 1990; REIS, 2003; SOARES, 2008), que não desistiram de "afirmar através de muitos meios sua vontade e assim, sua humanidade" (REIS, 2008).

Nas duas primeiras seções, não tenho a intenção de realizar uma revisão bibliográfica sobre o tema, mas tão somente apresentar algumas pesquisas que considero importantes, tomando-as como representativas dos estudos sobre/com crianças negras nas últimas décadas do século XX e ainda nos dias atuais. Se aqui as tomo como modelo, é porque acabaram por direcionar o debate científico sobre este grupo intergeracional e racial. Em uma última seção, finalizo com aquilo que vejo como sendo as contribuições que as crianças negras podem trazer para os estudos sociais da infância, a partir da constituição de novas perguntas e novos problemas.

Um dos objetivos desta seção é, por exemplo, é compreender de que modo as crianças se apropriam, fazem uso ou reinventam os modelos que nós construímos para explicar as relações de raça. Assim como Antonio Guimarães (2003), defendo que "não existem conceitos que valham sempre em todo lugar, fora do tempo, do espaço e das teorias" (p. 95); desse modo, 
o conceito de raça aqui é visto não apenas como uma categoria política necessária para organizar a resistência ao racismo no Brasil, mas é também categoria analítica indispensável: a única que revela que as discriminações e desigualdades que a noção brasileira de "cor" enseja são efetivamente raciais e não apenas de "classe" (GUIMARÃES, 2002, p. 50). Outras pesquisas utilizam o conceito na mesma perspectiva, ao pesquisar com crianças (OLIVEIRA, 2004; TRINIDAD, 2011; GAUDIO, 2013; SANTIAGO, 2014).

Segundo Renata Prado (2014)

os estudos sociais da infância constituem-se como um campo de conhecimento em construção, que, em síntese, partilha entre si a visão das crianças como atores sociais com significativa participação na construção da história e da cultura (CORSARO, 2011), a visão da infância como construção social (JAMES; PROUT, 1997) e, também como categoria estrutural subordinada da sociedade (QVORTRUP, 2010a) [...] Os paradigmas propostos pelos estudos sociais da infância tem orientado pesquisas nas áreas de história, pedagogia, antropologia, economia, saúde e psicologia, apesar de suas sistematizações mais elaboradas virem da sociologia, mais especificamente, da sociologia da infância. (PRADO, 2014, p. 18)

Estes estudos reivindicam que as crianças sejam ouvidas porque, assim como os adultos, são pessoas que também fazem parte da sociedade e tem muito que falar sobre suas próprias experiências de estar no mundo. Em contraposição à imagem de um sujeito universal - masculino e adulto, visto como pronto - invoco aqui a imagem das crianças - um grupo de pessoas em crescimento, entendendo que estar em crescimento denota movimento, mudança, ações importantes para construir novos olhares sobre os problemas sociais brasileiros. Assim, as observações destas sobre o mundo que as cercam nos convocam a olhar de novo para temas importantes da sociedade brasileira, questionando não apenas o status de completude vinculada à adultez, mas também o modelo que utilizamos 
Cadê as crianças negras que estão aqui?': o racismo (não) comeu’

para "debater" problemas, que não promove a inclusão e a participação de todas as pessoas presentes na sociedade brasileira.

No texto A criança negra, uma criança e negra, as autoras (2010) iniciaram o debate que retomo nesta segunda parte do artigo. Ao fazer um breve estado da arte sobre as pesquisas que falavam sobre crianças negras, as autoras denominaram de primeira fase - a expressão criança negra marca esse tempo - o momento em que a pesquisa

\begin{abstract}
denunciava o racismo existente na escola, na sociedade e que estava expresso nos indicadores econômicos e educacionais de todos os níveis de ensino. As pesquisas desta primeira fase demonstraram que raça é uma categoria analítica e deste modo, não deriva de nenhuma outra instância, seja ela econômica, por exemplo, que a determine (ABRAMOVICZ, OLIVEIRA; RODRIGUES (2010, p. 75)
\end{abstract}

As autoras informam que um pensamento que vê a criança negra como uma força minoritária, mas "molecular, positiva e não essencialista [...] poderia vir a compor um segundo momento das pesquisas sobre o negro, não só centrada na denúncia. Mas nas possibilidades de inversão e de produção de outras coisas sob a clave do negro, daquilo que ele difere e faz diferir" (Idem, p. 89). Para as análises aqui apresentadas, considera-se esta afirmação como potente, pois colabora para incorporarmos "o discurso das diferenças não como um desvio, mas como o mote de nossas práticas e das relações entre as crianças". (Idem, p. 92).

Apesar disso, em que pese a observação feita por Abramovicz e Oliveira (2012), que defendem não ser possível falar de uma "sociologia da infância que não leve em conta a raça" (p. 50) é importante ressaltar o debate racial não tem encontrado ainda a ressonância necessária nos estudos sociais da infância para demonstrar a presença das crianças negras, Este artigo, assim, busca contribuir com uma maior inserção do tema das relações raciais nestes campos de estudos pois, em sendo raça uma categoria utilizada no cotidiano de nossas relações sociais, não é possível olhar as infâncias - estas sempre plurais e em contexto - desconsiderando 
Míghian Danae Ferreira Nunes

de que modo a raça está presente nos processos sociais de constituição da pessoa.

O conceito raça não é exclusivo dos estudos com crianças negras, ele é também é importante para entendermos os processos pelos quais crianças brancas constituem-se e são constituídas. Apesar de Regina Pinto (1987) afirmar que os estudos sobre criança negra abordam a socialização das crianças brancas, à medida que "se percebe uma preocupação com os efeitos das representações estereotipadas do negro, dos preconceitos, não só na criança negra, mas também na branca" (p. 44), entendemos que este tema continua sendo pouco abordado nos estudos das relações raciais.

Apesar da emergência dos estudos sobre branquitude na produção acadêmica brasileira (CARDOSO, 2008), estes ainda não são feitos com crianças. Indico o trabalho de Luciana Alves (2010) como um dos poucos que, na área educacional, aborda o tema da branquitude na infância das pessoas que entrevistou. Ao reunir o tema das relações de raça e o tema da infância, é preciso relembrar que, apesar de raça ser um marcador identitário para as crianças, não podemos dizer que elas são responsáveis pela formulação do modo como vemos as relações de raça no Brasil, o que faz com que devamos ter cautela na afirmação de que elas reproduzem este ou aquele comportamento, já que esta assertiva desconsideraria a ação social das crianças.

\section{Contra o silêncio que acalenta o racismo: a escola e as crianças} negras

Antes de elaborar uma análise sobre as pesquisas realizadas com ou sobre as crianças negras nas áreas das ciências humanas, afirmo que, com algum esforço, as crianças negras podem ser encontradas nas pesquisas acadêmicas numa área que se convencionou chamar de história social da infância (PRIORE, 1999) ou historia social da infância brasileira (FREITAS, 2003), incluídas também na chamada história social da infância abandonada (MARCÍLIO, 1998). De um modo geral, sua presença também se faz notar em estudos historiográficos brasileiros (MATTOSO, 1988; CIVILETTI, 1991; FRAGA FILHO, 1994) e também nos estudos sobre a história da educação brasileira (BARROS, 2005; SILVA, 2000; MÜLLER, 2008a, 2008b; D'AVILA, 2006). Com algum esforço, as crianças negras podem ser encontradas, mas é perceptível que muitas vezes não foram completamente vistas e muito menos ouvidas. 
A falta de atenção destas pesquisas não é apenas às crianças negras, ela é extensiva a todas as crianças que, ao serem vistas como incapazes, não podem fazer parte do registro da história. Ocorre que os motivos pelos quais crianças negras e brancas não são vistas e ouvidas diferem qualitativamente e colaboram para demonstrar qual a importância da raça nos estudos sociais da infância: enquanto estas não são recebem atenção justamente por serem crianças, aquelas não recebem por não terem nem sido consideradas, por muito tempo, crianças.

Nesta primeira seção, apresento algumas pesquisas feitas em sua maioria em escolas brasileiras, buscando demonstrar como essas diferenças foram percebidas pelas pesquisadoras que nelas estiveram. Além dos trabalhos acadêmicos aqui apresentados, convém relembrar a série de artigos publicados nos Cadernos de Pesquisa, já que eles também alimentam o debate sobre relações raciais e infância desde o fim da década de setenta, apresentando relatos de pesquisas e de experiências das crianças negras na escola ${ }^{6}$, bem como as diferenças estatísticas entre o acesso e oportunidade de crianças negras e brancas na primeira etapa da educação básica no Brasil (ROSEMBERG, 1987, 1991, 1996, 1997, 2006; ROSEMBERG \& PINTO, 1997).

Em 1955, pesquisas realizadas pela socióloga e psicanalista Virginia Leone Bicudo e Aniela Ginsberg, psicóloga, foram feitas a partir de questionários, testes de bonecas e exibição de imagens com crianças entre 07 e 15 anos, buscando identificar se e como as crianças respondiam às perguntas utilizando o racismo como critério de classificação. Apesar de serem pesquisas que enfatizam resultados quantitativos com relação ao racismo - o que leva Ginsberg a concluir que, pelas análises estatísticas, o grupo pesquisado tivesse "pouca" tendência racista (p. 336), apesar de terem preferido marcadamente os brancos -, o pioneirismo destas não deve ser desconsiderado.

Estas pesquisas fizeram parte de um projeto amplo sobre relações entre negros e brancos realizado pela UNESCO no Brasil, com a coordenação de Roger Bastide e Florestan Fernandes. Estes estudos, vistos como complementares ao "inquérito propriamente dito" sobre as relações raciais no Brasil (DUARTE, 1955, p. 08) aparecem apenas em números da

${ }^{6}$ Em 1987 há um número especial dedicado ao tema, intitulado Raça negra e Educação. 
Míghian Danae Ferreira Nunes

Revista Anhembi em 1953 e no relatório publicado em 1955 (DAMACENO, 2013), mas não aparecem na publicação oficial do livro em 1959, publicado apenas com as pesquisas tidas como centrais no estudo. Convém destacar que este modo subalternizado de tratar estas pesquisas pode ter relação não apenas com o sexo das pesquisadoras, mas também por conta do grupo escolhido.

Em pesquisa intitulada Atitude dos alunos dos grupos escolares em relação com a cor dos seus colegas, Bicudo7 (1955) procurou evidenciar "1) - os sentimentos e os mecanismos psíquicos de defesa manifestos nas atitudes relacionadas com a cor dos colegas e 2) - a influência das relações intrafamiliais no desenvolvimento daquelas atitudes" (p. 227). Para isso, organizou uma amostra composta por 4520 escolares de 09 a 15 anos procedendo à entrega de questionários que versavam sobre a preferência e rejeição destas crianças com relação às/aos seus colegas.

Segundo Bicudo (1955) a conclusão é a de que “a criança é influenciada pelas atitudes dos pais com respeito às pessoas de cor, porém [...] ela as re-elabora, mantendo-as com maior ou menor tenacidade, segundo os afetos operantes nas relações com os pais" (p. 292). A autora também analisa que, apesar de muitas vezes as motivações para preferência e rejeição não serem definidas por critérios raciais, qualidades como "'bom', 'bom aluno', e 'bem educado' estariam associadas ao branco, como qualidades a ele peculiares" (p. 240). Além disso, o estudo revelou a existência de atitudes preconceituosas em relação a negros e mulatos (sic), a introjeção de ideais do branco e a transformação da palavra negro em xingamento.

Ginsberg (1955) observa as reações das crianças (07-14 anos) através de um jogo com duas bonecas - uma branca e uma preta - e da exposição de imagens representando cenas da vida de crianças brancas e pretas. A autora teve com a participação de crianças brancas e negras oriundas de classes sociais diferentes - duas escolas públicas e uma particular - chegou à conclusão de que

todos os examinandos de todas as cores e meios sociais mostram, em nossos resultados, marcada

7 No segundo capítulo da tese Os Segredos de Virgínia: Estudo de Atitudes Raciais em São Paulo (1945-1955) (DAMACENO, 2013) há uma apresentação da vida de Virgínia Leone Bicudo, ela mesma tendo sido uma das primeiras mulheres negras psicanalistas e professoras universitárias brasileiras. 
Cadê as crianças negras que estão aqui?': o racismo (não) comeu’

preferência pelos brancos. A maioria das crianças brancas mostra atitude amigável com os pretos dando-lhes portanto um lugar secundário e atribuindo-lhes, com bastante frequência, papel social inferior (p. 340).

Uma questão importante de ser observada é que, nestes estudos, realizados em grande parte em escolas públicas, o número de crianças negras é pequeno (somando as crianças classificadas como pretas e mulatas, o percentual é de $9,75 \%$ na primeira pesquisa e $19,7 \%$ na segunda), o que demonstra como estas ainda se encontravam fora da escola. Além desta observação, as duas pesquisadoras notaram que as meninas brancas eram mais "exclusivistas" (p. 232) que os meninos brancos em relação aos critérios raciais utilizados - apesar de Ginsberg apontar que estas diferenças não sejam "significativas estatisticamente" (p. 332) -, demonstrando que questões de sexo-gênero podem influenciar nas escolhas raciais.

Segundo Cruz, Abramovicz e Rodrigues (2015),

As impressões de Bicudo e Ginsberg articuladas a partir de uma ênfase teórica entre sociologia e psicologia social, demonstram a existência de um preconceito de cor independente do preconceito de classe, divergindo da análise corrente especialmente de Donald Pierson [...] essas investigações são pioneiras por articularem interseções de categorias etárias, de gênero, étnicas e raciais na interação social entre diversos grupos etários. (CRUZ, ABRAMOVICZ, RODRIGUES, 2015, p. 335)

As pesquisas acima mencionadas, ao fazerem parte de um documento que institucionaliza as ciências sociais brasileiras, inscrevem na pauta dos debates sociológicos, os estudos sobre infância e a agência da criança no que diz respeito a tema das relações raciais. Para as autoras, elas "podem ser alocadas em uma espécie de gênese histórica da pesquisa sociológica sobre as crianças e suas infâncias no contexto brasileiro" (Idem, p. 340). Estas pesquisas, ao demonstrarem que as crianças são 
interlocutoras capazes de realizar leituras sobre a realidade que as cerca, confirma ideias percebidas nas pesquisas antropológicas (MEAD, 1930, 1935). Com estes trabalhos, deu-se início à denúncia do racismo no espaço escolar, o que considero ser uma das primeiras formas de tornar audíveis as falas das crianças negras nas pesquisas acadêmicas.

Este modelo de pesquisa volta com alguma força durante as lutas dos movimentos sociais e negros na década de $80^{8}$, lutas estas que forçaram, entre outras coisas, a inclusão de artigos que versavam sobre a importância da educação brasileira considerar as contribuições das populações negras e indígenas na Constituição nacional (RODRIGUES, 2005) e também a promulgação do Estatuto da Criança e do Adolescente (Lei n. 8069/1990, ECA). Ainda assim, segundo Fazzi (2000), os estudos não seguiram analisando atitudes raciais como os aqui apresentados e deslocaram-se "para a discussão dos mecanismos de transmissão do preconceito, privilegiando a escola como reprodutora da desigualdade social e racial, além do debate em torno do papel dos meios de comunicação de massa, na transmissão de estereótipos raciais" (p. 282)9.

$\mathrm{Na}$ década de noventa, as pesquisas realizadas por Eliana de Oliveira (1994) e Eliane Cavalleiro (1998) foram feitas em escolas de educação infantil na cidade de São Paulo e também buscaram observar aspectos relacionados ao preconceito racial, ainda que sob diferentes perspectivas. Oliveira (1994) buscou descrever a composição racial do conjunto de crianças atendidas em algumas creches e pré-escolas, a partir das fotografias das crianças atendidas. Mesmo sem ouvir crianças, ao observar "uma tendência de as pessoas que se autoclassificam como brancas apresentarem as maiores proporções na atribuição da cor branca às crianças fotografadas" (p. 25), comparando-se às proporções apresentadas por pessoas autoclassificadas como pretas ou como pardas, podemos encontrar neste trabalho uma importante comprovação de como a heteroclassificação pode, em alguns casos, contribuir com o silêncio sobre a questão racial.

8 Segundo Cruz, Rodrigues e Abramovicz (2015), à exceção dos trabalhos apresentados, há uma lacuna sobre estudos da infância entre os anos 1940 e 1970 (p. 340).

9 Para um registro histórico, convém destacar os trabalhos de Maria Tereza Ramos Dias (1979), Irene Barbosa (1983), Luís Alberto Gonçalves (1985), Neusa Gusmão (1993), Eliana de Oliveira (1994) Eliete Godoy (1996). 
Cadê as crianças negras que estão aqui?': o racismo (não) comeu’

Cavalleiro (1998) estudou as atitudes de adultos e crianças com relação ao preconceito racial. Ao lado de outras pesquisas, estes trabalhos foram ao mesmo tempo fruto do debate dos movimentos sociais negros e importantes documentos para a produção do debate acadêmico sobre o tema, tornando visível um problema educacional brasileiro, que tinha suas raízes em um problema social que desde a Lei Áurea não havia sido encarado como deveria ${ }^{10}$. Durante as entrevistas que Cavalleiro $(1998 ; 2003)$ realizou com as professoras de educação infantil, podemos encontrar excertos em que as professoras, além de afirmar a existência do racismo, reiteram-no em suas observações (2003, p. 48-51). Apesar disso, afirmam também que ele não é notado entre as crianças que frequentam as turmas de educação infantil (2003, p. 46).

As observações realizadas pela pesquisadora no parquinho entre as crianças demonstram as afirmações não condizem com o que as crianças relatam ou é por ela observado durante o tempo em que passa na escola. Ao conversar com uma delas, Cavalleiro (2003) relata que

Aparecida [...] afirma, as crianças só brincam com ela quando "eu trago brinquedo. Porque eu sou preta. A gente estava brincando de mamãe. A Catarina branca falou: Eu não vou ser tia dela (da própria criança que está narrando). A Camila que é branca não tem nojo de mim".

- E a outras crianças têm?

-Têm. (2003, p. 45)

As pesquisas de Oliveira (1994) e Cavalleiro (1998) são primeiras dissertações a tratar das questões relacionadas à educação infantil e pertencimento racial. O silêncio surge como algo praticado de modo sistemático pela escola para resolver as tensões que as relações raciais provocavam na instituição escolar (GONÇALVES, 1985; CAVALLEIRO, 1998), identificando como as crianças são atingidas por ele, já que nas escolas pesquisadas não há espaço para o debate sobre como as crianças vivenciam a experiência de ser negra ou branca.

${ }^{10}$ Com o provérbio "em casa de enforcado não se fala em corda" (NOGUEIRA, 2006, p. 299), Oracy Nogueira define o modo como o Brasil tratou o tema das relações raciais por muito tempo nas ciências sociais. 
Assim como Barbosa (1983), Cavalleiro (1998) vê a escola como um dos primeiros espaços onde as crianças negras passam pelos primeiros confrontos interraciais. O silêncio da família com relação ao tema pode ser lido tanto como uma falta de preparo (BARBOSA, 1983) como uma forma de proteger a criança até que entre na escola (CAVALLEIRO, 1998). A escola, com o discurso de igualdade como intenção, torna-se um espaço fértil para que o "racismo silenciado" (MUNANGA, 1996) entre em ação. Ao não problematizar as diferenças e até mesmo rejeitá-las, cultiva a falsa ideia de que a democracia racial é algo presente na sociedade brasileira. Estes estudos confirmam que, sem olhar para a raça, não é possível falar numa educação de qualidade com racismo, algo reforçado por estudos estatísticos que datam da mesma época (HASENBALG, 1979; HASENBALG \&SILVA, 1990; ROSEMBERG, 1987, 1997) e mesmo alguns mais atuais (CARVALHO, 2011).

Buscando uma análise mais consoante com o que havia sido produzido pelas primeiras autoras aqui destacadas e apoiada numa literatura estadunidense sobre o tema, Rita Fazzi (2000) apresenta em sua tese algo que chamou de "drama racial da criança brasileira", quando esta foi publicada em formato de livro. Assim como Ginsberg (1955), Fazzi (2000) realizou a pesquisa com crianças denominadas por ela de pobres e de classe média em duas escolas públicas municipais de Belo Horizonte, utilizando a técnica de bonecas"11 "associada com uma lista de atributos positivos e negativos, dando a opção de não atribuição de atributos a nenhum dos bonecos, tentando, com isso, controlar a indução provocada pela escolha forçada" (p. 126).

Tal qual na pesquisa de Ginsberg (1955), "os resultados do jogo dos cartões, tanto no grupo de crianças pobres quanto no de classe média, indicaram uma tendência de valorização do branco, revelando, concomitantemente, atitudes preconceituosas em relação aos não-brancos" (p. 296)

\footnotetext{
${ }^{11 E n c o n t r a m o s ~ o ~ u s o ~ d e ~ b o n e c a s ~ e m ~ p e s q u i s a s ~ c o m ~ c r i a n c ̧ a s ~ s o b r e ~ r e l a c ̧ o ̃ e s ~ r a c i a i s ~}$ desde 1939, nos Estados Unidos, nos trabalhos de Ruth Horowitz. O trabalho de Kenneth Clark (1954) também pioneiro no uso de bonecas e pode ser visto no filme Separados, mas iguais (1991) que, ao retratar um processo judicial envolvendo crianças negras e o acesso à escola pública no sul dos EUA, mostra como advogados favoráveis ao fim das escolas separadas utilizou o teste das bonecas.
} 
Cadê as crianças negras que estão aqui?': o racismo (não) comeu’

Atitudes raciais negativas das crianças observadas em minha pesquisa foram,

inicialmente, discutidas a partir dos estereótipos preto é feio, preto parece diabo e ladrão é preto, que circulavam entre elas. A consideração de que preto é feio parece ser uma crença da teoria popular de raça e é generalizada nos dois grupos de crianças pesquisados. A forma quase automática em que essa avaliação estética foi feita pelas crianças me permitiu dizer que essa é uma crença já naturalizada: se é preto é feio (FAZZI, 2000, p. 284)

Além disso, ao buscar o ponto de vista das crianças sobre as relações raciais, Fazzi (2000) não utiliza o sistema bipolar de classificação - "negro e branco ou branco e não-branco" (p. 62) - por perceber que as crianças fazem o uso de maneira reiterada do termo moreno. O termo seria

por um lado, o reconhecimento de uma categoria intermediária e, por outro lado, o reconhecimento de um tipo de tratamento social considerado menos ofensivo que o uso dos termos negro ou preto, correspondendo ao comportamento, exigido pela etiqueta racial, de evitar ferir a suscetibilidade dos indivíduos classificados e percebidos como negros/pretos (p. 276).

O uso do termo moreno não é exclusivo às crianças desta pesquisa e tem sido analisado em pesquisas sobre as relações raciais no Brasil (SILVA, 1994; HASENBALG, 1979) que apontam que, justamente por ser considerado "um termo menos ofensivo", sua utilização pode colaborar com uma desmobilização política em torno das pautas dos movimentos sociais negros, que reivindicam uma classificação racial que leve em consideração que grupos negros (pretos e pardos) não tiveram o mesmo acesso e oportunidade aos direitos básicos humanos em nossa sociedade.

A pesquisa de Fabiana de Oliveira (2004) realiza um estudo de caso descritivo de natureza qualitativa numa creche da rede municipal de São Carlos (SP), analisando práticas educativas, verificando se aquelas 
Míghian Danae Ferreira Nunes

direcionadas especialmente para a criança negra são racistas. A pesquisa foi desenvolvida durante um semestre letivo, a partir de observações, anotações num diário de campo e entrevistas com pessoas adultas que trabalhavam no ambiente escolar. Apesar de ocupar-se das pessoas adultas que estavam com as crianças e não diretamente delas, esta pesquisa foi selecionada porque demonstra um esforço de apontar um novo modo de vista para as crianças negras.

Após permanecer na escola e observar as atitudes das pajens e professoras com relação às crianças, atitudes estas que incluíam questões relacionadas a gênero e raça, a autora usa o termo paparicação do mesmo modo que é usado por Ariès (1981) em seu livro História social da criança e da família - "a criança por sua ingenuidade, gentileza e graça, se tornava uma fonte de distração e de relaxamento para o adulto" (p. 82) - para identificar as práticas das profissionais que atuam na creche com relação às crianças negras e brancas. Nesses momentos, as crianças recebiam carinho e acolhimento por parte das profissionais da creche mas, pela observação realizada, as crianças negras e algumas crianças brancas que não estão entre as preferidas são excluídas destes momentos, o que para a autora

pode parecer negativo, mas não é, pois o âmbito relacional também é um aparelho de captura e controle, por isso, é preciso ver a positividade de estar fora desta prática. Assim, as crianças negras estavam excluídas de serem tratadas como bibelôs, bonecas, estando livres desse afeto inibidor, fraternal e familiar que asfixia e aprisiona. (2004, p. 93)

Partindo de uma concepção deleuziana, a autora segue dizendo que, ao estar fora, a criança negra "pode se transformar em outra coisa, diferente do modelo homogeneizante" (Idem, p. 95). Esta conclusão, ao buscar novos caminhos para compreender como as crianças negras avaliam as práticas que são dirigidas a elas não deve esquecer de além de enxergar relativa liberdade com relação ao controle que o afeto pode produzir, ouvir o que e como as crianças negras - e mesmo as brancas não escolhidas - sentem-se ao assistir estes momentos de paparicação. Entendo que não dispomos de larga experiência em ouvir crianças pequenas, mas também não é possível ter 
certeza que tornar-se outra coisa diferencie-se substancialmente daquilo uma criança negra já experimenta em seu cotidiano, marcadas que são por serem coisas, coisas estas ligadas à ausência e ao desvio.

Estes dois trabalhos buscam apresentar, ainda que de modo muito inicial, uma participação das crianças negras nos espaços nos quais estão presentes. Estes eventos marcam a presença das crianças e também nos convidam a observá-las não apenas sobre o que delas dizem, mas também a partir daquilo que elas fazem ou pensam. Assim, se nos primeiros estudos tínhamos a observação das crianças e a interpretação do que fazem, além do que dizem os adultos que estão ao seu redor, nestes há a tentativa ainda que incipiente, conforme ressaltei - de por a criança em evidência a partir de suas falas, ressignificando as ações que tomam referente ao tema das relações raciais.

Ir em direção à criança negra, encontrá-las, dar-lhe ouvidos. Estes parecem ser apontamentos que começam a despontar nas pesquisas apresentadas aqui, muito embora estas questões ainda não estejam tão aparentes nos objetivos apresentados inicialmente. Reiteramos que estes estudos são importantes para garantir a manutenção do debate sobre infâncias e relações raciais e por isso, responsáveis pelos estudos que serão apresentados a seguir.

Na segunda década do século XXI, estes trabalhos continuaram a influenciar a produção de pesquisas acadêmicas preocupadas em estudar como o racismo atingia as crianças negras. Alguns deles, amparados pela sociologia da infância, começaram a ouvir as crianças para compreender como estas significavam a questão da raça em suas vidas. Destes, escolhi apresentar dois trabalhos: a tese de Cristina Trinidad (2011) e a dissertação de Eduarda Gaudio (2013).

A pesquisa de Cristina Trinidad (2011) ouviu crianças de uma escola municipal de educação infantil a partir de uma abordagem etnográfica acerca do pertencimento racial destas, atentando para quais eram suas compreensões acerca das classificações existentes, buscando também perceber como estas classificavam familiares e colegas. Às questões centrais - como crianças em idade pré-escolar compreendem a identificação étnico-racial e quais são os critérios por elas utilizados (p. 161) -, a pesquisadora observou que as crianças 
já fazem uso das várias categorias utilizadas pelo IBGE [...] fazem pouco uso do termo "negro" para se autoidentificarem [...] a categoria preto foi utilizada pelas crianças participantes deste estudo em uma quantidade significativa de vezes [...] A hipótese levantada é que crianças em idades préescolares, conforme analisado anteriormente, fazem uso do preconceito e da discriminação, por meio do plano verbal e, à medida que vão adquirindo mais idade, tendem a transformá-los em atitudes, portanto valorando os vocábulos raciais diferentemente (p. 161-162)

Além disso, como nas pesquisas de Fazzi (2000) o termo moreno volta a surgir entre as crianças, o que nas observações da pesquisadora indicava que "encontrou-se mais desejo de possuir traços físicos brancos entre as crianças que se autodefiniram como 'morenas' do que em crianças que fizeram uso da categoria 'preto'" (p. 163). A autora conclui que "apreender quais os sentidos e significados mostra-se uma questão central para que se possa compará-los com os resultados obtidos juntos a adultos e adolescentes [...] talvez seja uma saída para entender se e quando se dão as rupturas em termos dos sentidos e significados dados à cor/raça" (p. 167).

Já a pesquisa em nível de mestrado de Eduarda Gaudio (2013) buscou na rede municipal de São José (SC) uma escola de educação infantil com o maior número de crianças negras para abordar as relações sociais. A partir de um estudo de caso etnográfico, a pesquisadora acompanhou uma turma na referida escola, notando que "as crianças exprimiam seus modos de ver e interpretar o mundo através do corpo e das relações étnico-raciais" (p. 152-153). A partir da observação das crianças, a dimensão corporal recebeu maior atenção, e a partir dela a autora organizou alguns apontamentos, demonstrando de que modo as crianças "expressavam seus saberes sobre o mundo recorrendo a dimensão corporal, como a força, a estatura, a agilidade, a fraqueza e a aparência" (p. 154). Ela percebeu "a recorrência de dimensões particulares que diferenciam e hierarquizam relações, sobretudo no que diz respeito aos elementos étnico-raciais, de gênero e aparência física" (Idem). 
Cadê as crianças negras que estão aqui?': o racismo (não) comeu’

Através da dimensão corporal, Gaudio (2013) pode fazer observações sobre a cor da pele e as categorias étnico-raciais utilizadas pelas crianças, momentos que ela relatou episódios semelhantes aos encontrados em trabalhos mais antigos sobre o tema (CAVALLEIRO, 1998; TRINIDAD, 2011). Além disso, a autora fez apontamentos sobre como as crianças lidavam com questões relacionadas à exaltação de uma beleza vinculada ao corpo branco magro, manifesta também no desejo de possuírem cabelos lisos e loiros. Uma das conclusões a que chega a autora afirma que

\begin{abstract}
Ainda que as exigências e os constrangimentos originários de uma ordem adulta sejam impostos rigidamente através das práticas pedagógicas, as crianças participantes dessa pesquisa resistiam a esses paradigmas demonstrando conhecer o sistema institucional vivenciado, elaborando estratégias pelas quais conseguiam escapar dessa estrutura organizacional, tais como: utilizar espaços e materiais que a sala possui para construir outras disposições, dar a refeição não desejada a um colega, levar brinquedos "proibidos" da sala para o espaço do parque, permanecer acordadas conversando com os colegas nos momentos em que todas as crianças devem dormir, entre outras. (2013, p. 211)
\end{abstract}

Estes trabalhos mais recentes seguem uma trilha aberta pelos primeiros estudos sobre infância e relações raciais, além de alimentarem-se dos estudos estatísticos aqui citados, realizados de maneira intensa a partir da década de 80 (ROSEMBERG, 1987, 1990) e também dos estudos sociais da infância, conjugando as teorias para fazer emergir nos textos, os pontos de vista das crianças. Paralelo a estes trabalhos, há o início de pesquisas que, sem desconsiderar os contextos em que estão as crianças negras, buscam escutá-las a partir do que elas são e o que fazem a partir daquilo que conseguem acessar. A proposta é, sem perder de vista os problemas sociais a que a população negra foi submetida, realizar um olhar de dentro e de muito perto das crianças, levando em conta aquilo que as afetam. Esta 
Míghian Danae Ferreira Nunes

parece ser a perspectiva apontada pelos estudos comentados na seção que segue.

\section{Denunciar e (re)existir: as crianças negras que estão aqui!}

Nesta seção, optei por trazer alguns trabalhos que, além de apontar o racismo presente nas instituições escolares e na vida das crianças negras, apresentou como as crianças negras estão aqui, apesar do sistema de opressões a qual estão subordinadas. Adultocentrismo, racismo e sexismo são experiências que as afetam, mas as crianças não são engolidas por elas: aludir a estes processos de resistência na constituição das crianças negras é parte importante para que possamos enxergá-las em contexto. Reivindico que estes estudos não se tornem lados de uma mesma moeda - polares - mas sim, complementares, buscando romper com certa tradição maniqueísta que define "ou isso ou aquilo" para conclusões sobre nossos problemas sociais.

O trabalho realizado por Flávia Damião (2007), intitulado Primeira infância, afrodescendência e educação no Arraial do retiro, Salvador traz um debate acerca da diversidade da infância presente em nossa sociedade, enfatizando o contexto como importante elemento de análise das infâncias brasileiras. A autora realizou a pesquisa com crianças do bairro onde morava em Salvador, encontrando as crianças durante seu próprio percurso no bairro, realizando as entrevistas com crianças com idades entre 03-09 anos, a partir de uma abordagem inicial e o consentimento das crianças para, posteriormente, solicitar a permissão das/os responsáveis.

Segundo Damião (2007), o beco e a rua eram espaços de convivência das crianças e se impunham como lugares em que a infância por ela estudada ganhava corpo (p. 47). A partir das andanças realizadas com as crianças nas ruas dos bairros e também dos encontros em que registros foram feitos - fotografias e desenhos -, a autora defende que

no Arraial do Retiro há uma multiplicidade de arranjos da vida infantil. [...] Ali, se pode entrever que nem mesmo em um pequeno território a infância afrodescendente se constitui como sendo um movimento exclusivo. Isso me possibilitou questionar de modo mais enfático o discurso da 
infância como fenômeno sócio-histórico único e universal (p. 135).

Ao entender que a observação das infâncias deve levar em consideração aspectos como "os pertencimentos étnicos, territorial, etário, social e de gênero em meio a uma interpenetração das dimensões individual e coletiva" (p. 9), a pesquisadora pôde, a partir desse fluxo intercomunicativo, reconhecer

as crianças do grupo participante como pessoas com efetiva participação na construção de suas próprias experiências e cultura, bem como, na elaboração da realidade dos adultos [...] Desta forma, não há possibilidade de repetição, no plano externo, do movimento da experiência que as crianças daquela territorialidade empreendem (p. 136).

Pelo mesmo caminho, entre as pesquisas que buscam apresentar as crianças negras a partir do que são e não apenas do que lhes faltam, encontramos algumas delas feitas com crianças quilombolas ${ }^{12}$. Entre estas, escolhi apresentar as pesquisas realizadas por Eliana de Paula (2014) e Márcia Lúcia Souza (2015) por serem aquelas que apresentam de maneira mais satisfatória as ideias a que esta seção se propõe divulgar ${ }^{13}$.

A tese de Eliana de Paula (2014) foi realizada em dois quilombos próximos à Garopaba (SC) chamados Morro do Fortunato e Aldeia, tendo a pesquisadora estudado com as crianças quilombolas entre 04 e 06 anos e algumas crianças da escola de educação infantil frequentada por aquelas. Paula (2015) vê o que chama de relativa autonomia nas crianças do quilombo em relação às crianças que vivem fora dele, já que lá, ao brincarem nas ruas do quilombo, brincam "sem ter que prestar contas, que brincam, brigam, choram, ficam de mal, fazem as pazes e começam tudo de

\footnotetext{
${ }^{12} \mathrm{Na}$ tese de Souza (2015) há um quadro com os trabalhos encontrados por ela no banco de teses e dissertações da CAPES (p. 73-80). Segundo a autora, uma das primeiras pesquisas que utilizam a sociologia da infância como aporte teórico para pesquisar crianças quilombolas é de Arilma Spindola, realizada em 2008.

${ }^{13}$ A tese de Eliana de Paula (2014), realizada em quilombos de Garopaba (SC) é um trabalho anterior ao de Souza (2015).
} 
novo... a cada dia e de acordo com seus mundos de vida, e portanto, pela perspectiva da infância e não do mundo adulto" (p. 196).

Buscando romper a ideia de que as crianças negras são apenas vítimas de um destino já anunciado, qual seja, o da submissão à lógica adulta, a pesquisadora percebe que há uma reivindicação das crianças à participação efetiva no cotidiano do quilombo, ação social possível, entre outros motivos, pelo fato das crianças sentirem-se pertencentes ao lugar onde vivem. Nesta relação entre o quilombo e a escola, Paula (2015) deu especial atenção ao contexto em que as crianças viviam, entendendo este como potencial para a construção de uma infância solidária e comunitária, que era possível de ser observada em crianças muito pequenas (p. 195).

A partir das observações realizadas nas andanças das ruas do quilombo com as crianças e as adultas, a pesquisadora notou que, também a partir do corpo - e não apenas da oralidade -, as crianças relacionavam-se com as pessoas que estavam com elas de maneira mais horizontal que o comum (p. 241). Já na escola, a autora aponta que as crianças do quilombo passam por situações de preconceito racial que muito lembram uma das pesquisas já apresentadas aqui (CAVALLEIRO, 1998), fazendo com que algumas delas, na escola, não falassem sobre o lugar onde moram.

"O que fazem as crianças quilombolas? Como vivem a infância num território específico?" (SOUZA, 2015, p. 240) foram algumas das primeiras perguntas que orientaram o trabalho da pesquisadora Márcia Lúcia Souza, que percorreu com as crianças os espaços do Quilombo Brotas em Itatiba (SP), na tentativa de perceber como organizavam suas culturas infantis, que surgiram relacionadas ao território, ao jongo ${ }^{14} \mathrm{e}$ também às/aos adultas/os do lugar. É certo que "as questões em torno da terra, das desigualdades sociais, raciais e econômicas, os preconceitos raciais e o racismo" (p. 245) estão presentes na infância quilombola. Ainda assim, a pesquisadora afirma que "as culturas infantis mostram que existem processos de

\footnotetext{
${ }^{14}$ Segundo o Instituto de Patrimônio Histórico e Artístico Nacional (IPHAN), o jongo é "uma forma de expressão afro-brasileira que integra percussão de tambores, dança coletiva e práticas de magia. É praticado nos quintais das periferias urbanas e de algumas comunidades rurais do sudeste brasileiro [...] O jongo é uma forma de louvação aos antepassados, consolidação de tradições e afirmação de identidades. Tem suas raízes nos saberes, ritos e crenças dos povos africanos, principalmente os de língua bantu (IPHAN, 2005).
} 
Cadê as crianças negras que estão aqui?': o racismo (não) comeu’

aprendizagem em que as crianças são sujeitos ativos diante de adultos que transmitem formas de pensar e agir" (p. 243).

As crianças do Quilombo Brotas, ao brincarem, aprendem sobre o lugar a partir de uma lógica própria, entre o possível e o impossível, as muitas certezas e dúvidas, num trânsito entre a multiplicidade de sentidos para os lugares, sua materialidade e imaterialidade constitutiva. [...] Enquanto crianças negras, a cultura infantil da qual fazem parte denuncia espaços de negação e silenciamento de sua origem étnico-racial. Um deles é a escola [...] $\mathrm{Na}$ relação com este espaço institucional e instituinte as crianças quilombolas preferem não dizer de si, evitando o confronto com um Outro que não entende sua territorialidade e o contexto histórico-social de sua existência no passado e no presente. (SOUZA, 2015, p. 244)

Esta pesquisa indica assim que a escola, um dos espaços em que a população negra brasileira tem buscado adentrar desde antes mesmo do fim da escravização continua a silenciar as crianças quilombolas e suas experiências, diferente do Quilombo, onde as crianças mostram-se mais autônomas, alegres e seguras, tendo assim nessas ambivalências os caminhos de aceitação e rejeição de quem são. Aqui também, as crianças muitas vezes evitam falar onde moram na escola (p. 206). Nas duas pesquisas apresentadas, as autoras apontam o quilombo como um espaço de maior autonomia para as crianças, onde vivem com intensidade o tempo de experimentar ser criança, algo definido como importante para as pesquisadoras.

O último trabalho apresentado nesta seção é o de Flávio Santiago (2014), que em sua dissertação descreve a etnografia que realizou num centro de educação infantil (CEI) numa cidade da região de Campinas/ São Paulo, onde analisou "a violência do processo de racialização sobre a construção das culturas infantis" (vii). A partir de visitas regulares ao CEI por quatro meses, o autor observou como as "crianças pequenininhas" respondiam às violências direcionadas a elas por conta de seu 
pertencimento racial e como reelaboravam as relações com as pessoas adultas que as haviam agredido. Ao ouvir as crianças, Santiago registra em seu diário de campo relatos semelhantes aos encontrados por pesquisas anteriores. Para além das descrições destes acontecimentos, o autor destaca a importância de enxergarmos a ação social das crianças nestes momentos de conflitos raciais, entendendo que estas não respondem passivamente às agressões cotidianas. Segundo ele,

os choros, as rebeldias e as brigas expressavam como as crianças negras percebiam o racismo presente nas posturas pedagógicas adotadas, explicitando que não aceitavam os enquadramentos que as fixavam em posições subalternas na sociedade. Através de diferentes movimentos de choque com o poder, os meninos e meninas negras instauravam sentidos e "rabiscavam" suas configurações corpóreas, lançando-se para o novo, resistindo [...] (2014, p. 62).

O autor busca, ao analisar as ações sociais das crianças, desmontar certa ideia de que definem motivos únicos para a interpretação dos choros das crianças, demonstrando que eles podem ser também, espaço de reivindicação do desejo que possuem de serem ouvidas, o que implica, para as crianças negras, o desejo de não serem discriminadas por serem negras. Apesar de concordar sobre a que pessoas adultas devem ter com o tema do racismo na escola e na sociedade como um todo, podemos também, a partir de um ponto de vista não-adultocêntrico, compreender de que maneira as crianças tem reelaborado o contato com estas questões desde muito cedo, o que poderá nos ajudar a encontrar outras respostas para o combate ao racismo na escola.

Segundo Márcia Gobbi (1997) “o termo adultocêntrico aproxima-se aqui de outro termo bastante utilizado na antropologia: o etnocentrismo: uma visão de mundo segundo a qual o grupo ao qual pertencemos é tomado como centro de tudo e os outros são olhados segundo nossos valores, criando-se um modelo que serve de parâmetro para qualquer comparação. Nesse caso o modelo é o adulto e tudo passa a ser visto e sentido segundo a ótica do adulto, ele é o centro" (p. 26). Em suas 
Cadê as crianças negras que estão aqui?': o racismo (não) comeu’

considerações, Santiago (2014) aponta que "o adultocentrismo não permite olhar e ouvir o que as crianças pequenininhas querem nos transmitir, nos deixando amarrados em padrões de linguagens e de comportamentos que muitas vezes não correspondem a "intempestividade" da própria infância" (p. 112). Precisamos estar atentos para construir

\begin{abstract}
pedagogias da infância preocupadas em não reproduzirem $\mathrm{o}$ adultocentrismo $\mathrm{e}$ o racismo presentes na sociedade, de modo a nos questionarmos sobre a possibilidade de "escutas e olhares invertidos" que nos ajudem a compreender as linguagens infantis, e também problematizar as concepções pedagógicas relativas às relações étnicoraciais na educação infantil. (Idem)
\end{abstract}

Nos trabalhos apresentados nesta seção, vemos que a tentativa de aproximação dos mundos das crianças deu-se a partir da escuta sensível não apenas ao que elas diziam, mas também ao que faziam em seus cotidianos. A participação das crianças nas pesquisas é uma forma de garantir que suas ideias sejam levadas em conta, mas entendemos que entre os direitos de participação e de proteção das crianças pode haver choques, em especial se estivermos lidando com crianças tornadas vulneráveis (KRAMER, 2002; SANTANA, 2011; BARBOSA, 2012). Apesar dos impasses, eles não devem motivar a exclusão das crianças das pesquisas, mas tão somente para reforçar a importância de refletirmos sobre os modelos de pesquisas estabelecidos e a ética presente pesquisas que envolvam seres humanos.

De todo modo, as pesquisas apresentadas são inovadoras porque apontam não apenas que as crianças negras participam da vida em sociedade, mas que também podem alterar a percepção dos/as adultos/as que estão ao redor delas, questionando as relações intergeracionais e de poder existentes. Das quatro pesquisas apresentadas nesta segunda seção, três delas tinham a "rua" como espaço principal de observação, mesmo tendo sido defendidas em programas de pós-graduação em Educação. Esta constatação pode indicar que estudos em escolas formais tornam difícil a observação da ação social das crianças negras, não apenas por conta do racismo institucional existente em nossas instituições escolares, mas 
também do racismo cotidiano, impetrado nas relações estabelecidas entre e com as crianças. Essa afirmação reforça o que diz Rosemberg (1991) em relação ao fato da educação

despertar entre certos segmentos negros reações ambíguas: de um lado, a percepção recorrente de sua importância no processo de mobilidade social, seja na perspectiva da ascensão seja na perspectiva da manutenção do status atingido [...]; de outro, a ameaça que a escola veicula enquanto instituição branca. (p. 92)

Apesar de concordar que a escola não deve ser o único lugar onde as crianças devam estar, é necessário estar atenta para que esta afirmação não mascare o fato de que a escola continua sendo um lugar onde as crianças negras não estão presentes. Na próxima e última seção deste artigo, organizei algumas perguntas que podem ser o ponto de partida para o reconhecimento de novos problemas com os quais os estudos sociais da infância vão se deparar, quando olharem para as crianças em seus contextos.

\section{Cutucando os estudos sociais da infância: o que as crianças negras fazem perguntar}

Nesta última seção, após a apresentação e análise de alguns trabalhos que estudaram com e sobre as crianças negras, algumas perguntas surgem, sugerindo também novos problemas com relação aos temas elencados. Incluir estas perguntas é evocar um dos exercícios mais conhecidos das crianças, um dos que atestam o vínculo delas a um tempo de aprender - tempo este que não deve ter fim com a chegada da adultez. Estas perguntas ensejam caminhos de pesquisas futuras com as crianças, sem a intenção inicial de apontar respostas únicas para os problemas levantados.

\section{1) Como as crianças veem a participação social delas numa sociedade que é racializada?}


As crianças vivem numa sociedade que, por mais que não se queira ver racializada, mantém uma série de ações e atividades que denotam que este marcador é utilizado para definir lugares e espaços ${ }^{15}$.Percebem também que o mundo em que vivem é um mundo adulto e neles, dificilmente conseguem reconhecimento de que são pessoas e fazem parte. Pouco a pouco, porém, percebem que esta participação é cada vez mais restrita, de acordo com sua condição de raça, classe e gênero. Como lidam com essas percepções? Como reelaboram, dentro de suas relações raciais, estas apreensões? Como e quando percebem que as categorias acima apresentadas estão em intersecção? Em quais momentos da infância elas acessam estes elementos raciais e de gênero para identificar-se e reforçar sua autoestima e em quais não?

É importante perceber se ou como a luta dos movimentos sociais negros e as políticas sociais de inclusão brasileiras colaboraram para alterações do olhar das crianças para com o tema. Em 2015,num evento do qual participei com uma comunicação, um dos participantes revelou interesse nas percepções das crianças filhas de militantes de movimentos sociais negros às questões raciais. Estes contextos diferenciados criam ambientes que certamente mudam o modo como estas crianças lidam com questões relacionadas à participação social.

Em contextos de participação infantil, como nas redes municipais escolares que possuem conselhos mirins escolares, por exemplo, será importante mapear se ou como raça é utilizada nos espaços de tomada de decisão e criação de políticas para as crianças. Assim como gênero, a raça pode ser ou não levada em consideração quando da organização dos grupos de trabalho e também na eleição das pautas de interesse das crianças.

Além disso, é importante ressaltar que não apenas crianças negras tem a experiência de viver num país racializado e, nesse sentido, todas estas perguntas podem - e devem! - ser feitas para crianças autodeclaradas brancas, indígenas e amarelas, tanto quanto possível. Desse modo, estaremos colaborando para que a questão da raça não seja visto como um

\footnotetext{
${ }^{15}$ Uma criança poderá notar, por exemplo, ao vir à Faculdade de Educação da USP, que todas as atendentes da lanchonete da Faculdade são negras e quase todas/os as/os professoras/es são brancas/os, mesmo que a ela não seja dito e ela não verbalize sobre o assunto. Consultar PORTER, Judith, 1973.
} 
Míghian Danae Ferreira Nunes

"problema do negro brasileiro" (RAMOS, 1981).

2) Como as crianças negras percebem a relação entre cor de pele/atributos físicos e raça versus poder e hierarquia social?

Estudos realizados com crianças pequenas - alguns deles já citados aqui - observam que as crianças começam a perceber como as diferenças raciais operam no cotidiano em que vivem entre três e cinco anos (PORTER, 1973; ABOUD, 1987; GODOY, 1996; CAVALLEIRO, 1998; TRINIDAD, 2011). Assim, as perguntas sobre o tema das relações raciais devem incluir a observação de em quais momentos e como as crianças começam a perceber que as/os adultas/os associam raça e cor da pele/atributos que denominamos físicos - cabelo, nariz, compleição física, habilidades corporais, entre outros - e como elas mesmas passam a valorar estas relações em suas interações com outras crianças e as/os adultas/os.

Sabemos que a questão da raça está para além de tais atributos, incluindo questões históricas, econômicas, políticas e de poder, mas percebo que uma das primeiras dimensões que abarcam a questão da raça e com a qual as crianças se deparam relacionam-se com aspectos relacionados ao corpo (FAZZI, 2000; GUIZZO, 2011; BUSS-SIMÃO, 2012, 2013; AMARAL, 2013; GAUDIO, 2013). Compreender como crianças negras - pretas e pardas, com pele mais clara, pele mais escura, cabelo crespo, cabelo cacheado - se veem e veem seus pares a partir da "dimensão corporal" (BUSS-SIMÃO, 2013, p. 23) é um problema importante a se considerar.

Problemas de pesquisa que levem em consideração a representação das crianças negras com relação a artefatos culturais brinquedos, filmes e livros, por exemplo - demonstram preocupação em responder esta pergunta, muito embora eles também sejam escassos, tendo maior produção os trabalhos que versam sobre a literatura infantil (SOARES, 2012; BISCHOFF, 2013). Pesquisas sobre como os binômios natureza/cultura surgem no debate sobre as crianças e a dimensão corporal destas - incluindo aí questões de raça - pensada aqui como constructo social, mas que nem por isso desvencilhada de questões da biologia podem também ajudar a compreender estes fenômenos sociais.

3) Quais as questões relacionadas ao debate sobre relações de 
Cadê as crianças negras que estão aqui?': o racismo (não) comeu’

\section{raça afetam as crianças, por elas mesmas?}

Apesar de dizerem que "deixam as crianças falar", muitas pesquisas podem apenas revelar certo preconceito geracional e enfatizar o poder atribuído às pessoas adultas por nossa sociedade, em que são elas que outorgam poder a alguém para dizer alguma coisa. Assim, estudos sobre as relações raciais com crianças podem ser realizados apenas para a comprovação de o que racismo não é algo inato e sim, adquirido. Esta orientação de pesquisa ocorre em parte porque, no Brasil, durante muito tempo, o racismo não era encarado como um problema social brasileiro, mas como um problema de grupos específicos.

Estas pesquisas se fazem necessárias e importantes para entendermos como nos constituímos, mas é preciso também ouvir as crianças para saber por quais motivos elas discutem questões relacionadas às relações de raça, ou seja, como as pesquisas sobre raça podem colaborar para a compreensão das experiências infantis e não apenas como teste da existência do racismo em nossa sociedade. Nessa perspectiva, estudos longitudinais podem fornecer importantes informações sobre como as crianças se veem e são vistas e como esse tema surge em seu cotidiano.

Um dos exemplos de como os estudos sobre relações raciais ocuparam-se por muito tempo da comprovação do racismo em nossa sociedade foi o fato de termos dado pouca atenção ao modo como a população branca, indígena e amarela vivem a experiência da raça. Pesquisas que abordem o tema da branquitude entre as crianças serão bemvindas para compor o quadro dos estudos das relações raciais. Assim, precisamos não apenas de estudar os problemas que nós levamos às crianças, mas também de conhecer melhor as crianças e quais são os seus problemas, aproximando-se assim, de saber se e como, em seus próprios termos, as crianças inventariam uma sociologia.

A raça esteve, durante muito tempo, vinculada exclusivamente a um determinismo biológico. Após a Segunda Guerra Mundial, seu uso foi reivindicado também por parte das ciências sociais como uma categoria analítica das relações em sociedade (GUIMARÃES, 2003). A discussão do tema, portanto, está vinculada ao debate que se faz sobre natureza e cultura, entendidas aqui não como polos estanques, mas como campos de interação das práticas sociais humanas. A infância, sendo também este entremeio, espaço híbrido onde natureza e cultura interagem, torna-se um 
Míghian Danae Ferreira Nunes

bom lugar para questionarmos a naturalização de discursos, sejam eles raciais, culturais ou de idade. Ouvir as crianças, como elaboram e incorporam os discursos e ações vistas e ouvidas sobre estes temas pode ser também um bom mote à pesquisa acadêmica.

\section{4) Como as crianças brancas vivenciam a experiência da raça?}

As populações autodeclaradas negras e brancas são aquelas em maior quantidade no Brasil, (50,7\% de negras/os e 47,7\% de brancas/os, segundo o Censo IBGE 2010). Apesar de não serem consultadas em pesquisas censitárias, é possível considerar que neste número estão refletidas as crianças. Assim, estas são as populações que, guardada as devidas diferenças regionais, estão em maior interação em espaços públicos como a escola, parques e outros. A partir destas informações, penso ser importante compreender como as crianças brancas têm vivido a experiência de ser criança num país que no início do século XX buscou projetar uma ideia de nação a partir de ideais eurocêntricos. Nesse contexto, faz-se necessário discorrer como as diferenças de sexo-gênero, classe e origem entre as crianças brancas também podem alterar a percepção destas sobre a realidade social.

As crianças brancas estão presentes nas pesquisas que abordam as relações raciais, algo que podemos perceber pelas pesquisas aqui analisadas (BICUDO, 1955; GINSBERG, 1955; FAZZI, 2000, CAVALLEIRO, 1998; TRINIDAD, 2011; GAUDIO, 2013). Apesar disso, elas não são observadas a partir da raça que pertencem, mas respondem às indagações sobre a raça da população negra, como se elas mesmas não fossem racializadas. Este é, aliás, uma das questões apontadas pelos estudos da branquitude (CARDOSO, 2008; ALVES, 2010), qual seja, o fato de que as pessoas brancas, por conta de um estereótipo que torna a brancura universal, se veem e são vistas como norma, tornando invisível o debate sobre branquitude que devem fazer parte das discussões das relações raciais no Brasil.

Uma constatação presente nos estudos sobre branquitude apontam que pessoas brancas desfrutam de privilégios por serem brancas. Imagino que, em relação aos demais grupos de crianças brasileiras, as crianças brancas podem ocupar lugares diferentes destes, determinados pela raça. Nesse sentido, não cabe apenas apontar que há ausências em ser criança na 
sociedade brasileira, algo que tem sido evidenciado pelos estudos sociais da infância, mas seguir perguntando quais as ausências tem nos escapado e como elas operam quando incluímos aí raça ou o gênero, por exemplo. É preciso compreender não apenas em que momento as crianças brancas aprendem que fazem parte da norma, mas também perguntar se e como as crianças brancas percebem estas diferenças e em que medida se utilizam desse marcador na relação com as pessoas e no ambientes em que convivem. As pesquisas que já realizamos nas escolas e em nos demais espaços em que as crianças estão presentes podem incluir esta reflexão, colaborando para ampliar o debate das relações raciais e infância.

\section{5) E as meninas negras?}

Com a interseccionalidade, chegamos às meninas negras. Este termo foi cunhado por Kimberlé Crenshaw(1989) para informar que

a associação de sistemas múltiplos de subordinação tem sido descrita de vários modos: discriminação composta, cargas múltiplas, ou como dupla ou tripla discriminação. A interseccionalidade é uma conceituação do problema que busca capturar as consequências estruturais e dinâmicas da interação entre dois ou mais eixos da subordinação. Ela trata especificamente da forma pela qual o racismo, o patriarcalismo, a opressão de classe e outros sistemas discriminatórios criam desigualdades básicas que estruturam as possíveis relativas de mulheres, raças, etnias, classes e outras ${ }^{16}$. (CRENSHAW, 2002, p. 177)

\footnotetext{
${ }^{16}$ É possível dizer que a origem do termo "remonta ao movimento do final dos anos de 1970, conhecido como Black Feminism (cf. Combahee River Collective, 2008; Davis, 1981; Collins, 1990; Dorlin, 2007), cuja crítica coletiva se voltou de maneira radical contra o feminismo branco, de classe média, heteronormativo" (HIRATA 2014, p. 62). No Brasil, no final da década de 70, esta discussão começou a ser realizada por mulheres negras - Lélia Gonzalez e Beatriz Nascimento, para citar algumas - dentro do movimento negro e do movimento de mulheres dos quais
} 
Como as mulheres negras, este grupo também está exposto às opressões vividas por elas, relacionando estas opressões ao fato de serem crianças, ou seja, a idade aqui surge como mais um eixo de subordinação. Assim, cabe também aos estudos que desejem discutir relações raciais entre as crianças a atenção para estas intersecções, que podem oferecer caminhos de pesquisas e novos problemas. Convém perguntar se e como o racismo e sexismo a que as mulheres negras são submetidas alteram as percepções do ser menina/ser mulher, como estas meninas negras constroem sua autoestima ou veem sua participação na sociedade elas têm enfrentado as opressões a que estão submetidas.

No livro O olho mais azul, Toni Morrison (2003), ao falar das mulheres negras, ela demonstra que, a partir desse olhar, há um lugar ocupado pelas crianças, este atravessado pela idade e a raça:

Depois cresceram. Entraram devagar na vida pela porta dos fundos. Transformaram-se. Todo mundo podia lhes dar ordens. As mulheres brancas diziam "Façam isso". As crianças brancas diziam "Me dá aquilo". Os homens brancos diziam "Venha cá". Os homens negros diziam "Deita". As únicas pessoas de quem não precisavam receber ordens eram as crianças e as outras mulheres negras. (p. 139)

O livro discorre sobre as relações das mulheres negras com as crianças e em particular com as meninas negras, que ocupavam um lugar específico de subalternidade não apenas com relação às pessoas negras adultas, mas também em relação às outras crianças brancas. Outro exemplo possível de ser observado está no famoso conto Negrinha, de Monteiro Lobato (2008), analisado por Ione Jovino (2105), em que é possível perceber que Negrinha - uma menina negra sem nome - também está relegada a um lugar que só ocupa por ser menina e negra. Estes dois exemplos, extraídos de textos literários - mas representativos de um grupo do qual pouco se encontram referências de trabalhos acadêmicos - podem ajudar na

faziam parte, resultando numa intensa produção acadêmica na década de 80 . Consultar: RATTS, 2007; RATTS \& RIOS, 2010. 
Cadê as crianças negras que estão aqui?': o racismo (não) comeu’

construção de exercícios analíticos mais abertos, que abarquem as categorias atravessadas nos cotidianos das meninas negras. Estudos sobre como se dão as escolhas dos pares para as festividades escolares, como são formados os grupos de amizade ou quais os estereótipos fixados para as meninas negras são bons motes à pesquisa acadêmica que busca debater os pontos de vista das crianças negras.

A partir destas perguntas, penso ser possível ampliar o debate já iniciado pelas pesquisas apresentadas nas seções anteriores, buscando também provocar novas perguntas e novas respostas ao questionamento que aparece no titulo deste artigo.

\section{Considerações finais}

A partir das análises dos estudos sobre relações raciais e infância realizadas por pesquisadoras/es brasileiras/os desde a década de cinquenta no Brasil foi possível perceber três momentos de trabalho, que guardam relação com os contextos históricos e os atores sociais que se movimentavam à época em que as produções foram concebidas. Percebe-se assim, no primeiro destes três momentos, na década de cinquenta, pesquisas que estavam vinculadas ao próprio nascimento da sociologia no Brasil e que buscavam identificar de que modo o racismo estava presente no espaço escolar e nas relações sociais das crianças e jovens.

Nas décadas que se seguiram, o silêncio foi quebrado a partir do início da década de oitenta, com a publicação de trabalhos na área da educação que seguiram denunciando o mesmo silêncio que acometia as pesquisas científicas com relação aos temas, silêncio este que também estava presente no modo como a escola lidava com as crianças negras. Este primeiro momento segue sendo replicado em diversas pesquisas acadêmicas no país (ver como exemplo ALMEIDA, 2016).

Nas décadas posteriores até a década de dez, esta tônica acentuouse e parte do que foi iniciado em pesquisas sociológicas na década de cinquenta migrou para a área da educação (com alguns trabalhos também na área da psicologia). A partir desta década, iniciou-se uma escuta mais sistemática daquilo que as crianças tinham a dizer, momento este que caracterizo como segundo momento das pesquisas que entrelaçaram relações raciais e infância. Nestes dois momentos, a criança negra carregou uma dupla marca vinculada à ideia de ausência ou falta, característica não 
Míghian Danae Ferreira Nunes

apenas do marcador infância como também da população negra.

No terceiro momento destas pesquisas, convoco as pesquisas mais recentes na área das relações raciais e dos estudos sociais da infância que intencionam marcar a presença das crianças pelo que elas são e pelo que podem fazer, levando em consideração o modo como vivem suas próprias vidas, elaboram suas experiências e constroem saberes especializados dos seus mundos infantis. Este terceiro momento comporta pesquisas realizadas fora e dentro da escola, o que demonstra que as crianças negras estão presentes e podem ser ouvidas não apenas em espaços informais de educação, mas também na escola. Além disso, estes trabalhos procuraram ouvir o que as crianças negras têm falado não apenas sobre a experiência do racismo, mas suas experiências sensíveis sobre raça, origem, gênero e pertencimento.

Se as crianças negras que estavam aqui foram comidas pelo racismo em algum momento de nossa história, nota-se que foram engolidas vivas e, dentro de algum bicho papão por aí, pulam e fazem barulho, teimando em serem ouvidas. Esperemos, enfim, que a partir de nossa ação conjunta com as crianças, num futuro bem próximo, não haja mais "pixotes, pivetes, capitães de areia" (NASCIMENTO, 1983) e nem barrigas de bicho papão.

\section{Referências bibliográficas:}

ABOUD, Frances E. The Development of ethnic self-identification and attitudes. IN: J. S. Phinney e M. J. Rotheram, Children's Ethnic Socialization. Newbury Park, SAGE Publications, 1987.

ABRAMOVICZ, Anete; OLIVEIRA, Fabiana de. As relações étnico-raciais e a sociologia da infância no Brasil: alguns aportes. In: Maria Aparecida Silva Bento (Org.). Educação infantil, igualdade racial e diversidade: aspectos políticos, jurídicos, conceituais. São Paulo, SP: Centro de Estudos das Relações de Trabalho e Desigualdades - CEERT, 2012. Disponível em: http://www.ceert.org.br/src/pdf/anete-abramowiscz-e-fabiana-deoliveira.pdf. Acesso em: 15.12.2016.

ALMEIDA, Saulo Santos Menezes. O processo de socialização de crianças e o desenvolvimento moral das mães: estudos sobre expressão de conteúdos e traços estereotípicos de crianças brancas e negras acerca da cor de pele. Tese (Doutorado - Programa de Pós-graduação em Psicologia) -Universidade Federal da Bahia. Salvador, 2016 
Cadê as crianças negras que estão aqui?': o racismo (não) comeu’

ALVES, Luciana. Significados de ser branco - a brancura no corpo e para além dele. Dissertação (Mestrado). Faculdade de Educação da Universidade de São Paulo, USP, 2010.

ALVIM, Maria Rosilene Barbosa; VALLADARES, Lícia do Prado. Infância e sociedade no Brasil: uma análise de literatura. BIB - Boletim Informativo e Bibliográfico de Ciências Sociais. Rio de Janeiro, n. 26, p. 3-37, 2ºmestre 1988.

ARIÈS, Philippe. História social da criança e da família. 2 ed. Rio de. Janeiro: LTC, 1981.

BARBOSA, Irene M. F. Socialização e Relações Raciais: um estudo de família negra em Campinas. Faculdade de Filosofia, Letras e Ciências Humanas da Universidade de São Paulo, USP, São Paulo, 1983.

BARBOSA, Maria Carmen Silveira. A ética na pesquisa etnográfica com crianças: primeiras problematizações. Práxis Educativa, Ponta Grossa, v. 9, n. 1, p. 235-245, jan.jun. 2014235 Disponível em: http://www.revistas2.uepg.br/index.php/praxiseducativa/article/view/6389/ 3914. Acesso em: 15.12.2016.

BARROS, Surya AARONOVICH Pombo de. Negrinhos que por ahi andão: a escolarização da população negra em São Paulo (1870-1920). Dissertação (Mestrado). Faculdade de Educação da Universidade de São Paulo, USP, 2005.

BICUDO, Virginia Leone. Atitude dos alunos dos grupos escolares em relação com a cor dos seus colegas. In: BASTIDE, Roger; FERNANDES, Florestan. Relações raciais entre negros e brancos em São Paulo. São Paulo: Editora ANHEMBI, 1955.

BISCHOFF, Daniela Lemmertz. Minha cor e a cor do outro: qual a cor dessa mistura? Estudos sobre racialidade a partir de pesquisa com crianças na educação infantil. Dissertação (Mestrado). Faculdade de Educação da Universidade Federal do Rio Grande do Sul, UFRGS, 2013.

BRASIL, República Federativa do. Estatuto da criança e do adolescente: Lei federal no 8069, de 13 de julho de 1990. Rio de Janeiro: Imprensa Oficial, 2002.

BUSS-SIMÃO, Márcia Relações sociais em um contexto de educação infantil: um olhar sobre a dimensão corporal na perspectiva de crianças pequenas. Centro de Ciências da Educação da Universidade Federal de Santa Catarina, UFSC. Florianópolis, SC, 2012. 
Míghian Danae Ferreira Nunes

Relações sociais de gênero na perspectiva de crianças pequenas na creche. Cadernos de Pesquisa, São Paulo, v. 43, n. 148, p. 176 197, abr. 2013.

Cadernos de Pesquisa: Raça negra e Educação [online]. Número 63, São Paulo, Fundação Carlos Chagas, 1987. Disponível em: http://publicacoes.fcc.org.br/ojs/index.php/cp/issue/view/96. Acesso em: 15.12.2016.

CARDOSO, Lourenço. O branco "invisível": um estudo sobre a emergência da branquitude nas pesquisas sobre as relações raciais no Brasil (Período: 1957 . 2007). Dissertação (Mestrado). Universidade de Coimbra, Portugal, 2008.

CARVALHO , Marília Pinto de. Avaliação escolar, gênero e raça. Campinas, SP: Papirus, 2009.

CAVALLEIRO, Eliane. Do silêncio do lar ao silêncio escolar: Racismo, preconceito e discriminação na Educação Infantil. Dissertação (Mestrado).Faculdade de educação da Universidade de São Paulo, FE-USP, 1998.

Do silêncio do lar ao silêncio escolar: racismo, preconceito e discriminação na educação infantil. $2^{a}$ edição. São Paulo: Contexto 2003.

CHALHOUB, Sidney. Visões de liberdade: uma história das últimas décadas da escravidão na Corte. São Paulo: Companhia das Letras, 1990.

CIVILETTI, Maria Vittoria Pardal. O cuidado às crianças pequenas no Brasil escravista. Cadernos de Pesquisa, São Paulo (76), fev 1991, p. 31-40. Disponível em: http://www.fcc.org.br/pesquisa/publicacoes/cp/arquivos/848.pdf. Acesso em: 15.12.2016.

CRENSHAW, K. Demarginalizing the intersection of race and sex: A black feminist critique of antidiscrimination doctrine, feminist theory and antiracist politics. The University of Chicago Legal Forum, 1989, pp.13967.Disponívelem: http://philpapers.org/archive/CREDTI.pdf. Acesso em: 15.12.2016..

CRI. Articulação para o combate ao racismo institucional. Identificação e abordagem do racismo institucional. Brasília: CRI, 2006.

CRUZ, Ana Juvenal; ABRAMOVICZ, Anete; RODRIGUES, Tatiane Cosentino. A pesquisa sobre criança e infância no Projeto UNESCO. Revista Eletrônica de Educação, v. 9, n. 2, p. 331-345, 2015. Disponível em: http://www.reveduc.ufscar.br/index.php/reveduc/article/view/1213/413Ace sso em: 15.12.2016.

Latitude, Vol. 10, nº 2, pp. 383-423, 2016 
Cadê as crianças negras que estão aqui?': o racismo (não) comeu’

DAMACENO, Janaína. Os Segredos de Virgínia: Estudo de Atitudes Raciais em São Paulo (1945-1955). Tese (Doutorado). Faculdade de Filosofia, Letras e Ciências Humanas da Universidade de São Paulo, USP, 2013.

DAMIÃO, Flávia de Jesus. Primeira infância, afrodescendência e educação no Arraial do retiro, Salvador. Dissertação (Mestrado em Educação). Faculdade de Educação da Universidade Federal do Ceará, UFC, 2007.

DÁVILA, Jerry. Diploma de brancura: política social e racial no Brasil (19171945). São Paulo: Editora Unesp, 2006.

DIAS, Maria Tereza Ramos. Desigualdades Sociais e Oportunidade Educacional - a produção do fracasso. Tese (Mestrado). Instituto Universitário de Pesquisas do Rio de Janeiro, IUPERJ, 1979.

DUARTE, Paulo. Prefácio. In: BASTIDE, Roger; FERNANDES, Florestan. Relações raciais entre negros e brancos em São Paulo. São Paulo: Editora ANHEMBI, 1955.

FAZZI, Rita de Cássia. Preconceito racial na infância. Tese (Doutorado). Instituto Universitário de Pesquisas do Rio de Janeiro (IUPERJ) , 2000.

FRAGA FILHO, Walter. Mendigos e vadios na Bahia do século XIX. Dissertação (Mestrado). Programa de pós-graduação História da faculdade de Ciências Humanas da Universidade Federal da Bahia, Salvador, BA, 1994.

FREITAS, Marcos Cezar de (Org.). História social da infância no Brasil. São Paulo: Cortez, 2003.

GAUDIO, Eduarda Souza. Relações sociais na educação infantil: dimensões étnico-raciais, corporais e de gênero. Dissertação (Mestrado em Educação). Faculdade de Educação da Universidade Federal de Santa Catarina, 2013.

GINSBERG, Aniela Meyer. Pesquisas sobre as atitudes de um grupo de escolares de São Paulo em relação com as crianças de cor. In: BASTIDE, Roger; FERNANDES, Florestan. Relações raciais entre negros e brancos em São Paulo. São Paulo: Editora ANHEMBI, 1955.

GOBBI, Marcia Aparecida. Lápis vermelho é de mulherzinha: Desenho infantil, relações de gênero e educação infantil. Dissertação de mestrado em Educação, Faculdade de Educação, FE-UNICAMP, Campinas, 1997.

GODOY, Eliete Aparecida. A representação étnica por crianças pré-escolares: um estudo de caso à luz piagetiana. Dissertação (Mestrado em Educação). Faculdade de Educação da Universidade Estadual de Campinas, FEUNICAMP, Campinas, SP, 1996. 
GONÇALVES, Luiz Alberto Oliveira. O silêncio: um ritual pedagógico a favor da discriminação racial: (um estudo acerca da discriminação racial como fator de seletividade na escola pública de primeiro grau - $1^{\underline{a}}$ a $4^{\underline{a}}$ série). Dissertação (Mestrado). Faculdade de Educação da Universidade Federal de Minas Gerais, UFMG, 1985.

GUIMARÃES, Antonio Sérgio. Classes, raça e democracia. São Paulo: Editora 34, 2002.

Como trabalhar com raça em sociologia. Educação e Pesquisa, São Paulo, v.29, n.1, p. 93-107, jan./jun. 2003. Disponível em: http://www.scielo.br/pdf/ep/v29n1/a08v29n1.pdf. Acesso em: 15.12.2016.

GUIZZO, Bianca Salazar. "Aquele negrão me chamou de leitão!": representações e práticas corporais de embelezamento na Educação Infantil. Dissertação (Mestrado). Faculdade de Educação da Universidade Federal do Rio Grande do Sul, UFRGS, 2011.

GUSMÃO, Neuza Maria Mendes de. Socialização e recalque: a criança negra o rural. Cadernos CEDES - Centro de Estudos Educação e Sociedade. Educação e Diferença Cultural: índios, negros; n. 32, São Paulo: Papirus, 1993 p. $49-84$.

HASENBALG, Carlos A. Discriminação e Desigualdades Raciais no Brasil. Tradução de Patrick Burglin. Rio de Janeiro, Graal, 1979.

HASENBALG, Carlos A; SILVA, Nelson do Valle. Raça e oportunidades educacionais no Brasil. Cadernos de Pesquisa, n. 73, maio, 1990, p. 5-12. Disponível

em:

http://publicacoes.fcc.org.br/ojs/index.php/cp/article/view/1092. Acesso em: 15.12.2016.

HIRATA, Helena. Gênero, classe e raça: interseccionalidade $e$ consubstancialidade das relações sociais. Revista Tempo Social, revista de sociologia da USP, v. 26, n. 1, 2014. Disponível em: $<$ http://www.revistas.usp.br/ts/article/view/84979/87743>. Acesso em: 15.12.2016.

HOROWITZ, Ruth. Racial aspects of self-identification in nursery school children. Journal of Psychology: Interdisciplinary and applied, 7, p. 91-99, 1939.

Instituto de Patrimônio Histórico e Artístico Nacional, IPHAN. Jongo: patrimônio imaterial brasileiro. 2005. Disponível em: 
Cadê as crianças negras que estão aqui?': o racismo (não) comeu’

http://portal.iphan.gov.br/uploads/publicacao/Jongo_patrimonio_imaterial _brasileiro.pdf. Acesso em: 15.12.2016.

JOVINO, Ione da Silva. Crianças negras na história: Fontes e discursos sobre a breve infância permitida pelo escravismo oitocentista brasileiro. Revista Eletrônica de Educação, v. 9, n. 2, p. 189-225, 2015.

KRAMER, Sonia. Autoria e autorização: questões éticas na pesquisa com crianças. Cad. Pesqui. [online]. 2002, n.116, pp.41-59. Disponível em: http://www.scielo.br/pdf/cp/n116/14398.pdf. Acesso em: 15.12.2016.

MARCÍLIO, Maria Luísa. História social da criança abandonada. São Paulo: Hucitec, 1998.

MATOSO, Kátia de Queirós. O Filho da Escrava (Em Torno da Lei do Ventre Livre). Revista Brasileira de História, São Paulo, mar/ago 1988, pp. 37-55. Disponível

em:

http://www.anpuh.org/arquivo/download?ID_ARQUIVO=3674. Acesso em: 15.12.2016.

MEAD, Margareth. Growing up in New Guinea: a comparative study of primitive education. New York: William Morrow, 1930.

MEAD, Margareth. Sex and temperament in three primitive societies. New York: William Morrow, 1935.

MORISSON, Toni. O olho mais azul. São Paulo: Companhia das Letras, 2003. MÜLLER, Maria Lúcia Rodrigues. A cor da escola: imagens da Primeira República. Cuiabá: EDUFMT/Entrelinhas, 2008a.

. Educadores \& alunos negros na Primeira República. Brasília:

Ludens, Rio de Janeiro: Fundação Biblioteca Nacional, 2008b.

MUNANGA, K. As facetas de um racismo silenciado. In: SCHWARCZ, L. QUEIROZ, R. S. (Org.) Raça e diversidade. São Paulo: Edusp, 1996, p.2 13229.

NASCIMENTO, Abdias do. Olhando no espelho. In: NASCIMENTO, Abdias do. Axés do sangue e da esperança: Orikis. Rio de Janeiro: Achiamé; Rio Arte, 1983, p. 71-73.

NOGUEIRA, Oracy. Preconceito racial de marca e preconceito racial de origem: Sugestão de um quadro de referência para a interpretação do material sobre relações raciais no Brasil. Tempo Social, revista de sociologia da USP, v. 19, n. 1, 2006. Disponível em: http://www.revistas.usp.br/ts/article/download/12545/14322. Acesso em: 15.12.2016. 
Míghian Danae Ferreira Nunes

OLIVEIRA, Eliana. Relações raciais nas creches diretas do Município de São Paulo. Dissertação (Mestrado em Psicologia Social). Pontifícia Universidade Católica de São Paulo, PUC-SP, 1994.

OLIVEIRA, Fabiana de. Um estudo sobre a creche: o que as práticas educativas produzem e revelam sobre a questão racial? Dissertação (Mestrado). Faculdade de Educação da Universidade Federal de São Carlos, UFSCar, 2004.

OLIVEIRA, Fabiana; ABRAMOWICZ, Anete; RODRIGUES, Tatiane C. A criança negra, uma criança e negra. IN: ABRAMOWICZ, Anete; GOMES, Nilma L. Educação e raça: perspectivas políticas, pedagógicas e estéticas. Belo Horizonte: Autêntica Editora, 2010, p. 75-96.

PAULA, Elaine de. "VEM BRINCAR NA RUA!": Entre o Quilombo e a Educação Infantil: capturando expressões, experiências e conflitos de crianças quilombolas no entremeio desses contextos. Tese (Doutorado). Faculdade de Educação da Universidade Federal de Santa Catarina, UFSC, 2014.

PORTER, Judith. Black Child, White Child - The Development of Racial Attitudes. Massachusetts: Harvard University Press, 1973.

PRADO, Renata Lopes Costa. A participação de crianças em pesquisas brasileiras das ciências sociais e humanas. Tese (Doutorado). Faculdade de Educação da Universidade de São Paulo, USP, 2014.

PRIORE, Mary Del (org.). História das crianças no Brasil. São Paulo: Contexto, 1999.

RAMOS, Alberto Guerreiro. O problema do negro na sociologia brasileira. In: SCHWARTZMAN, Simon. O Pensamento Nacionalista e os "Cadernos de Nosso Tempo". Brasília, Câmara dos Deputados e Biblioteca do Pensamento Brasileiro, 1981 [1954], pp. 39-69.

RATTS, Alex. Eu sou Atlântica: sobre a trajetória de vida de Beatriz Nascimento. São Paulo: Imprensa Oficial/Instituto Kuanza, 2007.

RATTS. Alex \& RIOS, Flávia. Lélia Gonzalez. 1a. Ed. São Paulo: Selo Negro, 2010.

REIS, João José [Orelha de livro]. In: SOARES, Carlos Eugênio Líbano. Acapoeira escrava. Campinas, SP: Editora UNICAMP, 20008.

. Rebelião Escrava no Brasil: A história do levante dos Malês em 1835. São Paulo: Companhia das Letras, 2003.

RIZZINI, Irene. O século perdido: raízes históricas das políticas públicas para a infância no Brasil. São Paulo: Cortez, 2008.

RODRIGUES, Tatiane Cosentino. Embates e contribuições do movimento negro à politica educacional nas décadas de 1980 e 1990. In: OLIVEIRA, Ione; Silva, 
Cadê as crianças negras que estão aqui?': o racismo (não) comeu’

Petronilha Gonçalves, Pinto, Regina Pinto (Orgs.). Negro e educação: escola, identidades, culturas e políticas públicas. São Paulo: Ação Educativa, 2004, p. 251-263.

ROSEMBERG, Fúlvia. Relações raciais e rendimento escolar. Cadernos de Pesquisa, n. 63, nov, 1987. Disponível em: http://www.fcc.org.br/pesquisa/publicacoes/cp/arquivos/787.pdf. Acesso em: 15.12.2016.

. Raça e educação inicial. Cadernos de Pesquisa, São Paulo, n.77,

p. 25-34, 1991. Disponível em:

http://www.fcc.org.br/pesquisa/publicacoes/cp/arquivos/839.pdf. Acesso em: 15.12.2016

Educação infantil, classe, raça e gênero. Cadernos de Pesquisa (Fundação Carlos Chagas), São Paulo, v. 96, p. 3-86, 1996. Disponível em:http://publicacoes.fcc.org.br/ojs/index.php/cp/article/view/814/824.

Acesso em: 15.12.2016.

Estatísticas educacionais e cor/raça na educação infantil e ensino fundamental: um balanço. Estudos em Avaliação Educacional, São Paulo, v. 17, n.33, p. 15-42, 2006. Disponível em: http://publicacoes.fcc.org.br/ojs/index.php/eae/article/view/2116/2074.

Acesso em: 15.12.2016.

ROSEMBERG, Fúlvia; PINTO, Regina Paim. Criança pequena e raça na PNAD 87. Textos Fundação Carlos Chagas/Departamento de Pesquisas Educacionais, São Paulo, v. 13, p. 01-90, 1997. Disponível em: http://www.fcc.org.br/pesquisa/publicacoes/textos_fcc/arquivos/1324/arqui voAnexado.pdf. Acesso em: 15.12.2016.

SANTANA, Juliana Prates. Trajetórias de vida de meninas em situação de rua: o relato de uma investigação. P O I É S I S, Tubarão, v. 4, n. 8, jul. 2011, p. 271 $-293$.

SANTIAGO, Flávio. "O meu cabelo é assim... igualzinho o da bruxa, todo armado": Hierarquização e racialização das crianças pequenininhas negras na educação infantil. Dissertação (Mestrado). Faculdade de Educação da Universidade Estadual de Campinas - FE/UNICAMP, 2014.

Separados mas Iguais. Direção: Versátil Home Vídeo, 1991, 1 DVD’ (192 minutos), NTSC, Color. Título Original: Separate but equal.

SILVA, Adriana Maria. Aprender com perfeição sem coação: uma escola para meninos pretos e pardos na corte. São Paulo: Editora Plano, 2000. 
Míghian Danae Ferreira Nunes

SILVA, Nelson do Valle. Uma nota sobre 'raça social' no Brasil. Estudos AfroAsiáticos, 26/ 67-80, 1994.

SOARES, Carlos Eugênio Líbano. A capoeira escrava. Campinas, SP: Editora UNICAMP, 20008.

SOARES, Poliana Rezende. Infância negra: uma análise da afirmação da identidade étnica a partir dos livros infantis. Dissertação (Mestrado). Faculdade de Educação da Universidade Federal da Paraíba/João Pessoa, 2012.

SOUZA, Márcia Lúcia Anacleto de. "Ser quilombola": identidade, território e educação na cultura infantil. Tese (doutorado). Faculdade de Educação da Universidade Estadual de Campinas, Campinas, SP: 2015.

SPINDOLA, Arilma M. A. A cultura da criança quilombola: leitura referenciada em estudo, relatos orais e imagens. Dissertação (Mestrado). Faculdade de Educação da Universidade Federal do Mato Grosso do Sul, Campo Grande, MS, 2008.

TRINIDAD, Cristina Teodoro. Identificação étnico-racial na voz de crianças em espaços de educação infantil. Tese (Doutorado). Pontifícia Universidade Católica de São Paulo - PUC/SP, 2011. 